\title{
特集 私なりの里海論・里海感・里海的取組
}

\section{Satoumi（里海）は国際的にどのように捉えられているか？ \\ 松田治 \\ NPO 法人 瀬戸内海研究会議}

How Satoumi is grasped internationally?

OSAMU MATSUDA

NPO the Research Institute for the Seto Inland Sea, Kobe, Hyogo 651-0073, Japan

\section{Satoumi は国際的によ゙のように表現されてきた} か?

はじめに，Satoumiが国際社会でどのように表現され てきたのか，できるだけ生（なま）の表現を以下に紹介 する。なお, Satoumi は Sato Umi, Sato-Umiなどとも 表記され，表示法が統一されていないが，本稿(本文中) では原記載にかかわらず Satoumi に統一する。

事例 1. Satoumi は "Symbiosis among human communities and coastal/marine areas- a more rational vision of co-existence” と表現された。これは, 第 7 回 EMECS 会議（EMECS7，フランス，カーン市，2006） の総括討論で，トルコのOhzan 教授が「Satoumiは人 間社会と沿岸海域の共生関係を示すもので，人と自然の より合理的な共存の未来像を示すもの」ととりまとめた ものである。この「共存」は沿岸域の利用と保全の両立 も意味している。

事例 2. EMECS conference will be remembered with the introduction of a new Japanese term into the international vocabulary. This term is Satoumi indicating the traditional approach of the Japanese people to the sea. $こ$ れは, EMECS8（中国，上海市，2008）のセッション 総括で Ohzan 教授が Satoumiに Tsunami や Kuroshio とならぶ国際用語としての評価を与えたものである。

事例 3. Satoumi places increased emphasis on promoting positive interaction between humankind and our enclosed coastal seas. That interaction can take many forms. It may be realized through concerted, continuous environmental conservation programs. 同じく EMECS8 では，最終日に採択された上海宣言に「Satoumi とは， 人類と閉鎖性海域との間の建設的な相互作用の促進を強 調する考え方」が盛り込まれた。

事例 4. Satoumi both as a concept and a management strategy provides a culturally-appropriate method for im- plementing provision of the Convention on Biological Diversity (CBD) related to coastal areas. On a very basic level, Satoumi is an expression of the CBD ecosystem approach, which is considered the primary framework for action under the CBD. これは, Marjo Vierros (2011)1) が，Satoumi と生物多様性条約や ecosystem approach との親和性を述べたものである。

事例 5. The concept of Satoyama, long-standing traditions associated with land management practices that allows sustainable use of natural resources, has been extended to cover marine and coastal ecosystem-Satoumi. ここでは, Satoumi がSatoyamaの概念を海洋や沿岸生 態系に拡張した概念であると表現されている（2012）。2)

事例 6. Satoumi is a term for coastal areas which has a strong connection with people's livelihoods; an area where people lead their lives by acquiring the diverse riches of the sea. Satoumi is high in productivity and serves as habitat to an abundant ecosystem that provides an important place for sea creatures to spawn and raise their fries. 人間生活との関連性を強調するこの表現は, 2011 年に石川県能登半島の Noto's Satoyama and Satoumi が FAO（国連食糧農業機関）の GIAHS（世界農業 遺産）として認定された際のSatoumiの説明文である。 以上 $6 つ$ 表現事例から, 国際的には Satoumi が人 と沿岸域の関係性を中心にしてかなり “守備範囲”の広 い概念や管理手法として表現されてきたことが分かる。 また，Satoumi は単独ではなくSatoyama と対にして用 いられることが少なくない点にも注意が必要である。つ まり，国際的にSatoumiを論じるにはSatoyamaの基本 的理解も必要である。

\section{2. 定義論の周辺と包括的概念規定としての Satoumi} 科学では一般に用語に厳密な定義が必要であるが，世 
間一般に広く使われている言葉では必ずしもそうでな く, 定義の不明確なものや定義のできないものも少なく ない。しかし，だからといって厳密に定義できない言葉 は意味がないとか役に立たない訳ではない。

世間一般で広く使われている言葉ではなくて，専門分 野でもう少し限定的に用いられる言葉の定義はどうであ ろうか？Satoumiにも関係の深い responsible fisheries（責任ある漁業）と wise use（賢明な利用）を取 り上げてみたい。Responsible fisheriesは FAO が提示 している考え方であり， wise use は湿地保全を主目的 とするラムサール条約の基本理念であるから，内容はと もに国際的にもよく認知されて抢り，むしろ時代の支持 を集めている概念でもある。しかし，では「責任ある漁 業」とは何か，「賢明な利用」とは何かを具体的に定義 し，端的に表現することができるかというとそうではな い。簡単にいえば，総論としての「責任ある漁業」や 「賢明な利用」の具体的なあり方（各論）は時と場所, 状況によって異なるのである。このように総論的な考え 方を定義することを包括的概念規定と呼んでみたい。前 項で示したSatoumiの国際的な取り上げられ方は, Satoumi がある種の包括的概念規定であることを示して いる。すなわち，Satoumi は定義論のレベルからすると responsible fisheries や wise use に近いということにな る。

Satoumi を包括的概念規定と考えると，A 国の B 湾 と C 国の D 浜の Satoumi には，総論的には共通性が認 めらても，具体的な表現形はそれぞれ異なるという状況 は当然のこととなる。この観点からは，B湾と D 浜の Satoumiの具体像が異なることは問題でなく，また，異 なるからといって打互いに Satoumiとして否定したり排 除したりすべきものでないことも明らかである。

\section{3. 国際会議と国際プロジェクトにおける Satoumi の 位置づけ}

ここでは, 国際会議や国際的なプロジェクトの中で Satoumi がどのように位置づけられてきたのかを，筆者 が参加した主な会議やプロジェクトについて紹介する。

EMECS 会議 EMECS は Environmental Management of Enclosed Coastal Seas の頭文字で，例えば EMECS9 は第 9 回世界閉鎖性海域環境保全会議を示す。 EMECS7（2006）では柳，松田から Satoumiの概念々 実践例が報告され，英盧湾のSatoumiづくりについて も複数の報告がなされたことが事例 1 をもたらした。 EMECS8（2008）ではSatoumiに特化したSatoumi Session が開催され，事例 2，3の表現に結びついた。 EMECS9（2011年，USA，ボルチモア市）のSatoumi Session はSatoumiの考え方をさらに広める（disseminate）ことが大きな目的となり，チェサピーク湾と
瀬戸内海の比較も重要なテーマとなった。

PEMSEA 関連会議 PEMSEA（東アジア海域環境管 理パートナーシップ）の主催する第 3 回 EAS-Congress (East Asian Seas Congress : 東アジア海域会議) が 2009 年にフィリピンのマニラ市で開かれた。この中の Satoumi Workshop のテーマは「生物生息地の保護と再 生管理に向けた地域固有のアプローチ：Satoumi の経験 と地域共同体主導の取組み」であった。Satoumi と ICM (Integrated Coastal Management) や CBM (Community Based Management）の関係性も重要なテーマ となった。筆者が議長を務め，第 1 セッションでは日 本の事例紹介，第 2 セッションではアジアの各国から 報告がなされた。これらを受けた第 3 セッションでは 非常に活発な総合討論が行われたが，これについては後 述する。

CBD 関連会議 CBD-COP10（生物多様性条約第 10 回 締約国会議）が 2010 年 10 月に名古屋で開催された。 この会議ではいわゆる愛知目標が決定され，これを機会 に日本でも生物多様性や海洋保護区（MPA： Marine Protected Area）に関する論議が盛んになったことはよ く知られている。この COP10では多くの Satoumi 関連 イベントが催され，またこれを契機として Satoumiを テーマにした CBD Technical series (2011)3) が刊行さ れることとなった。前記の表現事例 5 はこの中にあ る。関連した論議の中から Satoumi を active conservation（積極的な保全）として位置づける考え方も整理さ れた (Berque and Matsuda)。4)

Satoyama-Satoumi Sub-Global Assessment(SGA) 国連主導のミレニアム生態系評価の地域版が SGA であ る。日本ではじめての SGA が里山，里海をテーマにし て行われ, 成果は Satoyama-Satoumi and Human WellBeing として出版された。2)この中で, Seto Inland Sea as Satoumi ${ }^{5}$ )が評価された。Satoyama と Satoumi をつな ぐ発想 ${ }^{6}$ は沿岸域の総合的管理 (ICM) にも通じている。

\section{4. パラダイムシフトとしての Satoumi}

西欧，特にアメリカを中心にして発展してきた自然の 保護と利用を空間的に分離する考え方に対して，Satou$m i$ は，里山のようにいわば保全しながら利用する考え 方であるから，西欧流の沿岸域管理の考え方に新たな視 野を与えたといえる。さらに，前述のマニラでの Satou$m i$ Workshop（2009）の総合討論では新たな展開があ った。バリ島などの「人間は自然の一部である」という ヒンドゥー思想に基づく行動規範「トリ・ヒタ・カラー ナ」やフィリピンの伝統的持続的なマタウ漁業の紹介に 触発されて，会場からは「パラダイムシフトやライフス タイルの変更が必要ではないか」という提案が出される までの論議となった。詳しくは拙著7を参照していただ 
きたいが，Satoumiに関する論議がここまで及んだこと はSatoumiのもつ新たな萌芽的意味あいを示すものでも ある。

\section{5. まとめ}

Satoumi が国際的にどのように捉えられているかは， これまでSatoumiがどのように発信されてきたがにもも よっている。しかし, 現状で, Satoumiの捉えられ方 を, 端的, 具体的に述べるのは極めて難しい。なぜなら ば，Satoumi は前述のように包括的概念規定として捉え られている側面が非常に強いからである。従って，ここ ではSatoumiの総論的包括性についてまとめておきた い。その第 1 は沿岸域に打ける保全と利用の調和, 両 立性である。Satoumi は完全保護区や no take zone の ように保護一点張りでないが，利用中心の開発志向では なく，地域の知恵や伝統を重視した自然再生や生態系管 理を志向している。従って Satoumi は, CBM や EBM との親和性が強いのはもちろんのこと, ICM や MPA とも強い関係性を持っているのが特徵である。さらに最 後に触れたように，国際的にはパラダイムシフトや新た なライフスタイルへの志向性を内包しているといえる。

\section{文献}

1) Vierros M. Relevance of Satoumi to the CBD mandate. In: Secretariat of the Convention on Biological Diversity, Biological and Cultural Diversity in Coastal Communities-Ex- ploring the Potential of Satoumi for Implementing the Ecosystem Approach in the Japanese Archipelago, (CBD Technical series 61), Montreal. 2011; 2-7.

2) Duraiappah AK. Nakamura K, Tekeuchi K, Watanabe M, Nishi M (eds). Satoyama-Satoumi Ecosystems and Human Well-Being: Socio-Economic Production Landscapes of Japan. United Nations University Press, Tokyo. 2012.

3) Secretariat of the Convention on Biological Diversity, Biological and Cultural Diversity in Coastal Communities-Exploring the Potential of Satoumi for Implementing the Ecosystem Approach in the Japanese Archipelago, (CBD Technical series 61), Montreal. 2011.

4) Berque J., Matsuda O. Coastal biodiversity management in Japanese satoumi. Marine Policy 2013; 39: 191-200.

5) Matsuda O, Ebara A, Imai I, Inouchi Y, Ishikawa J, Kobayashi E, Terawaki T, Toda T., Tauchioka M, Ukita M, Yamashita Y, Yanagi T, Yuasa I, Zenitani H. Western Japan cluster: Seto Inland Sea as Satoumi. In: Duraiappah AK. Nakamura K, Tekeuchi K, Watanabe M, Nishi M (eds). Satoyama-Satoumi Ecosystems and Human WellBeing: Socio-Economic Production Landscapes of Japan. United Nations University Press, Tokyo. 2012; 381-402.

6) Matsuda O. Combining Activities of Sato-Umi and SatoYama in Japan: Towards a New Type of Integrated Coastal Watershed Management. In Taniguchi M., Shiraiwa T. (eds). The Dilemma of Boundaries, Springer, Tokyo, 2012; 211-220.

7）松田 治. アジアで深まるSato-Umi（里海）の認識. ア クアネット 2010; 3: 72-77.

8）松田 治. “Sato-Umi”（里海）の国際発信.「『里海』と しての沿岸域の新たな利用」(山本民次編) 恒星社厚生閣, 東京. 2010; 102-118. 